\title{
"Stat Rosa Pristina Nomine, Nomina Nuda Tenemus": The Many Syndromes, Diseases, and Anatomic Structures Bearing Jean-Martin Charcot's Name
}

\author{
Matheus Kahakura Franco Pedro ${ }^{a}$ Thiago Ferreira Simões De Souza ${ }^{b}$ \\ aDepartments of Neurology and Interventional Neuroradiology, Neurological Institute of Curitiba, Curitiba, Brazil; \\ ${ }^{b}$ Department of Neurology, Red Cross Hospital, Curitiba, Brazil
}

\section{Keywords}

History of neurology · Jean-Martin Charcot · Medical

eponyms

\begin{abstract}
The sheer magnitude of Jean-Martin Charcot's contributions to neurology, pathology, psychiatry, and internal medicine has allowed for the common usage of eponyms bearing the master's name in recognition of his work. However, these are so numerous that confusion has naturally arisen concerning the exact nature of each eponym, allowing for different specialists to refer to completely different ailments or symptoms, while using the very same expression. Previous compilations of his eponyms were often incomplete. Therefore, the authors aimed to bring some clarification into the nature and origin of each known eponym with Charcot's name.
\end{abstract}

(c) 2020 S. Karger AG, Basel

\section{Introduction}

"The ancient rose remains by its name, we only possess naked names," wrote the character Adso of Melk in the closing lines of "The Name of the Rose," by Eco [1]. As noted by Lodge in the foreword to the book's second edition in Portuguese [2], these words refer to the many and different meanings assigned to words during time, which may lead to confusion. Jean-Martin Charcot (1825-1893), widely considered the father of modern neurology, left such a wide and influential body of works in neurology proper, internal medicine, and psychiatry that a variety of anatomical structures, syndromes, diseases, and signs bear his name, and confusion on the meaning of these eponyms may easily arise [3-5]. For instance, both a neurologist and a gastroenterologist may have a patient presenting with Charcot's triad.

During his leadership, the Hôpital de la Salpêtrière became Europe's leading center on neurological sciences. He was an advocate of the anatomo-clinical method and led research in a wide variety of medical fields [6]; his pupils, such as Pierre Marie, Joseph Babinski, and Georges Gilles de la Tourette, among others, continued his legacy and enshrined the turn of the 19th to the 20th century in Paris as a golden age of neurology (Fig. 1).

While eponyms are discouraged nowadays, due to an often obsolete nature [7], they still serve as a reminder of neurology's illustrious past and have endured. Past reviews of Charcot and eponyms were incomplete and neglected a few entities [8]; therefore, the authors aimed to karger@karger.com www.karger.com/ene

(C) 2020 S. Karger AG, Base

Karger"
Matheus Kahakura Franco Pedro

Departments of Neurology and Interventional Neuroradiology Neurological Institute of Curitiba, Jeremias Maciel Perretto, 300 Curitiba Paraná 81210-310 (Brazil)

matheuskfpedro@ hotmail.com 


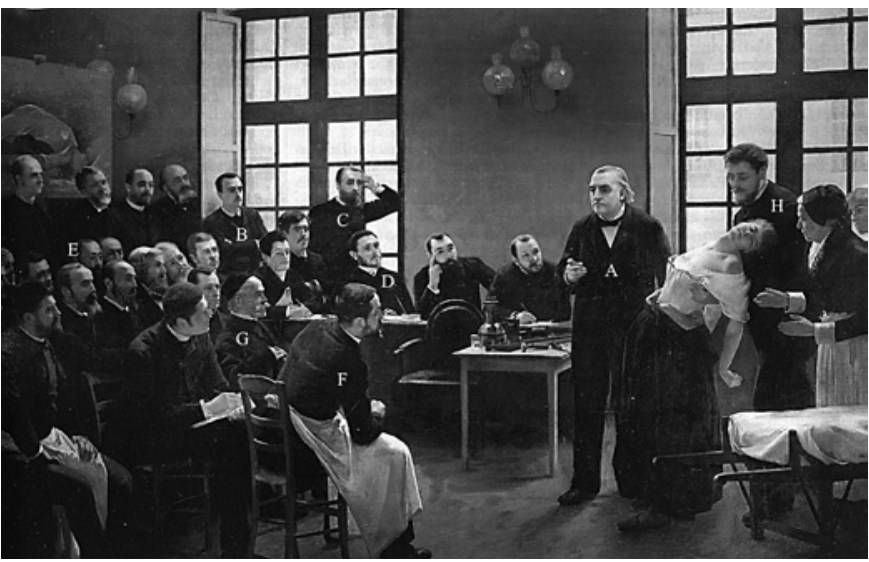

Fig. 1. Reproduction of André Brouillet's "Une leçon clinique à la Salpêtrière" from 1887. Jean-Martin Charcot (A) is represented alongside other physicians who would eventually appear as eponyms as well, including his son Jean-Baptiste Charcot (B), Alix Joffroy (C), Pierre Marie (D), and Albert Gombault (E). Others, whose eponyms, while not related to this article, achieved great importance in neurology, include Georges Gilles de la Tourette (F), Henri Parinaud (G), and Joseph Babinski (H). Available at https://en.wikipedia.org/wiki/A_Clinical_Lesson_at_the_ Salp\%C3\%AAtri\%C3\%A8re\#/media/File:Une_le\%C3\%A7on_ clinique_\%C3\%A0_la_Salp\%C3\%AAtri\%C3\%A8re.jpg, cited on June 05, 2020.

present a more comprehensive compilation. It is also worth noting that most of the eponyms range from 1853 to 1890 , showing a remarkable and continuous series of scientific investigations. Moreover, many of the eponyms originated long past Charcot's death and were given as a homage; even so, some are found only in older references, which makes establishing accurate dates a difficult task.

\section{Eponyms}

Charcot angina cruris (claudication intermittente): intermittent gait disturbance due to insufficient arterial supply to lower limb musculature; symptoms include pain, cramps, and weakness, usually appearing after physical effort and remitting after resting. It has been described by Charcot in $1859[9,10]$.

Charcot disease (sclérose latérale amyotrophique): the most common motor neuron disease; it is a progressive neurodegenerative entity which affects severely both upper and lower motor neurons. It is also known as Lou Gehrig's disease, after the deceased baseball player. It has been described by Charcot [11], with the anatomo-clinical definition following in 1869 with Charcot and Joffroy
[12] and the first use of the term "amyotrophic lateral sclerosis" in 1874 [13], though prior descriptions by Charles Bell, François Aran, Guillaume Duchenne de Boulogne, and Jean Cruveilhier exist [14]. It is known to this day as maladie de Charcot.

Charcot douche, or spinal douche: douches applied at la Salpêtrière for treatment of hysteria. A jet of $45-60^{\circ} \mathrm{F}$ water aimed at the patient's spine for $30 \mathrm{~s}$. It has also been described by the German psychiatrist Karl Wilhelm Ideler [15].

Charcot edema (oedème bleu des hystériques): edema with cyanosis of extremities found in patients with hysteria caused by application of tourniquet. It has been described by Charcot in 1890 [16].

Charcot foot or diabetic Charcot foot: related to Charcot joint; in this formulation refers specifically to the progressive degenerative arthropathy associated with diabetes. This disease on the feet may lead to ulcers and osteomyelitis. It has been described by Charcot in the specific context of diabetic osteoarthropathy [17].

Charcot hysterogenic points (zones hystérogènes): supposed hypersensitive zones which, when pressed, could provoke an attack of hysteria [18]. It has been described by Charcot in 1890 [19].

Charcot intermittent hepatic fever (fièvre hépatique): acute obstructive cholangitis. It has been described by Charcot [20] as related to his clinical triad, and this eponym has fallen out of current usage since the mid-20th century [21].

Charcot joint or Charcot neuropathic osteoarthropathy (pied tabétique): destructive joint disorder with bone and articular fragmentation of foot and ankle in patients with various peripheral neuropathies, such as syphilis. It has been described by Charcot in 1883 [22].

Charcot laryngeal vertigo or Charcot vertigo: the transient loss of consciousness due to glottic spasm resulting from a coughing spell, often accompanied by convulsions [23], classically reported on heavy smokers. It has been described by Charcot in 1876 .

Charcot ophthalmoplegic migraine (migraine ophtalmoplégique): paralysis of the oculomotor nerve in patients with migraine. It was first described by Gubler [24] 3 decades before Charcot in 1860. Charcot described it in 1890 , and actually, it is not a form of migraine but a recurrent ophthalmoplegic cranial neuropathy $[25,26]$.

Charcot spine or Charcot spinal arthropathy: progressive vertebral joint degeneration in the setting of loss of afferent innervation, involving the loss of deep pain and proprioception. It has been described by Charcot in syphilitic patients in 1868 [27]. 
Charcot triad (gastroenterology): fluctuating jaundice, intermittent fever with shivers, and recurrent pain in upper right abdominal quadrant. A sign of acute cholangitis, it is part of Reynolds' pentad with signs of shock (hypotension and tachycardia) and altered mental status described by Reynolds and Dargan [28]. It has been described by Charcot in 1877 [20, 29].

Charcot triad (neurology): nystagmus, intentional tremor, and scanning or staccato speech. Though not pathognomonic of multiple sclerosis, which Charcot himself acknowledged, it was described to differentiate the disease from Parkinson's disease. It has been described by Charcot in 1897 [30].

Charcot-Böttcher crystalloids: spindle-shaped crystalloids that can be found in Sertoli cells [31]; measuring up to $10-25 \mu \mathrm{m}$, they are proteinaceous and are originated by aggregation of intermediate filaments [23]. It has been described by Charcot and Arthur Böttcher.

Charcot-Bouchard aneurysm: aneurysms of the deep brain vasculature, originated from lenticulostriate arteries supplying basal ganglia, associated with chronic hypertension and whose rupture is a common cause of intraparenchymal hemorrhage. It has been described by Charcot and Charles Jacques Bouchard in 1867 in Bouchard's doctoral thesis [32].

Charcot-Gombault necrosis: biliary infarction, a late complication of extrahepatic cholestasis. It has been described by Charcot and Albert Gombault in 1876 [33].

Charcot-Joffroy syndrome, or idiopathic hypertrophic cervical meningitis, or epidural ascending spinal paralysis: amyotrophic lateral sclerosis-like syndrome with neck pain, sphincter disturbances, and vasomotor changes $[8$, 34]. It is associated with chronic granulomatous inflammation of cervical meninges. It has been described by Charcot and Alix Joffroy in 1873 in Joffroy's doctoral thesis [35].

Charcot-Leyden crystals or Charcot-Robin crystals: microscopic and intensely eosinophilic hexagonal crystals. They are found in allergic reactions, such as asthma, or parasitic infections, such as by Entamoeba hystolitic[36]. They have been described by Charcot and Charles-Philippe Robin in 1853 and by Ernst von Leyden in 1872, though first observed by Friedreich von Zenker in 1851 [8].

Charcot-Marie-Tooth disease, or hereditary motor and sensory neuropathy, or peroneal muscular atrophy (atrophie musculaire progressive): the most common inherited neuromuscular disorder. It is characterized by distal predominance of limb-muscle atrophy, weakness, and sensory loss, with high feet arches, hammer toes, and loss of proprioception usually following [37]. It has been described independently by Charcot and Marie [38] and Tooth [39] in 1886.
Charcot-Neumann crystals: while defined by Stedman [23] as a synonym of Charcot-Leyden crystals, they are described by Taber as a spermatic crystal [40].

Charcot-Weiss-Baker syndrome or carotid sinus hypersensitivity syndrome: syncope triggered by manipulation and compression of the carotid sinus, rotation of the neck, or use of tight collar. It is associated with bradycardia and hypotension. It has been described by Charcot with Soma Weiss and James Porter Baker, though it was first reported by Johann Nepomuk Czermak in 1866 [8].

Charcot-Wilbrand syndrome: a neuro-ophthalmic syndrome which consists of inability to mentally revisualize images along with visual agnosia. It has been described by Charcot [41] and Wilbrand in 1892 [42].

Erb-Charcot paralysis, or spinal spastic paralysis, or hereditary spastic paraplegia, or Strümpell-Lorrain syndrome (tabes dorsal spasmodique): rare neurological disorder characterized by gait abnormalities due to lower limb paresis and spasticity [43]. It has been described by Erb [44] and Charcotin [45-47], with further developments in the understanding of the disease by Adolf von Strümpell in 1886 and Maurice Lorrain in 1898 [43].

Souques-Charcot geroderma (géomorphisme cutané): rare genetic disorder causing symptoms resembling aspects of aging at an early age. Nowadays, recognized as a variant of the Hutchinson-Gilford progeria syndrome, after Hutchinson [48] and Hastings Gilford, it was described after them by Jean-Baptiste Charcot, son of JeanMartin Charcot, during his residency with his father, and Alexandre-Achilles Souques [49]; there is no evidence they knew of the preceding description.

\section{Conclusion}

A scholar of semiotics, Eco reveled in the polysemic title of his work; however, the same variety of meanings ascribed to a single word may generate confusion in the medical field. In this review, we have aimed to provide a comprehensive compilation of eponyms regarding Charcot in order to provide clarification.

\section{Statement of Ethics}

Due to the literature review character of the study, no authorization from an ethics research committee was required.

\section{Conflict of Interest Statement}

We have no conflict of interest to declare. 


\section{Funding Sources}

Due to the literature review character of the study, we had no specific funding to this research.

\section{Author Contributions}

Pedro, M.K.F.: research and composition of the manuscript. De Souza, T.F.S.: research and composition of the manuscript.

\section{References}

1 Eco U. O nome da rosa. 2nd ed. Rio de Janeiro: Record; 1980. p. 573.

2 Lodge D. Introdução. In: O nome da rosa. 2nd ed. Rio de Janeiro: Record; 1980. p. 9-26.

3 Broussolle E, Poirier J, Clarac F, Barbara JG. Figures and institutions of the neurological sciences in Paris from 1800 to 1950. part III: neurology. Rev Neurol. 2012;168(4):301-20.

4 Germiniani FMB, Moro A, Munhoz RP, Teive HAG. Onde está Gilles? Ou, o pequeno engano em uma cópia da pintura de Brouillet: "Uma lição clínica na Salpêtrière. Arq NeuroPsiquiatr. 2013;71(5):327-9.

5 Clarac F, Boller F. Chapter 40: history of neurology in France. Handb Clin Neurol. 2009; 95(C):629-56.

6 Goetz CG. Chapter 15 Jean-Martin Charcot and the anatomo-clinical method of neurology. In: Handbook of clinical neurology. 3rd ed. Elsevier B.V; 2009. Vol. 95; p. 203-12.

7 Mora B, Bosch X. Medical eponyms: time for a name change. Arch Intern Med. 2010; 170(16):1499-500.

8 Kundu AKR. Charcot in medical eponyms. J Assoc Physicians India. 2004;52(September): 716-8.

9 Charcot J-M. Note sur la claudication intermittente observée dans un cas d'oblitération complète de l'une des artères iliaques primitives. Rec Med Vet Ec AlfortSérie. 1859;IV(7): 481-94.

10 Charcot J-M. Sur la claudication intermittente observé dans un cas d'oblitération complète des artères iliaques primitives. Mémoires Comptes rendus des séances la Société Biol. 1859.

11 Charcot J-M. Sclérose des cordons latéraux de la moelle épinière chez uns femme hystérique atteinte de contracture permanente des quatre membres. Bull Mem Soc Med Hop Par. 1865:24-35.

12 Charcot J-M, Joffroy A. Deux cas d'atrophie musculaire progressive avec lésions de la substance grise et de faisceaux antérolatéraux de la moelle épinière. Arch Physiol Norm Pathol. 1869;2:628-49.

13 Charcot J-M. De la sclérose latérale amyotrophique. Progrès Médical. 1874;2:325-7.

14 Rowland LP. How amyotrophic lateral sclerosis got its name: the clinical-pathologic genius of Jean-Martin Charcot. Arch Neurol. 2001; 58(3):512-5.

15 Young Mde. Encyclopedia of asylum therapeutics, 1750-1950. Jefferson: McFarland \& Company, Inc.; 2015. p. 185-6.
16 Cooper MA, Davies DM. Charcot's oedème bleu des hystériques. J Hand Surg Br. 1985; 10(3):399-400.

17 Foster A. Problems with the nomenclature of Charcot's osteoarthropathy. Diabet Foot. 2005;8(3):134-42.

18 Da Mota Gomes M, Engelhardt E. Um viés neurológico na história da histeria: Desde o útero até o sistema nervoso e Charcot. Arq Neuropsiquiatr. 2014;72(12):972-5.

19 Teive HA, Germiniani FM, Munhoz RP. Overlap between fibromyalgia tender points and Charcot's hysterical zones: a historical curiosity. Neurology. 2015;84(20):2096-7.

20 Charcot J-M. Fièvre hépatique symptomatique. Comparison avec la fièvre uroseptique. Paris: Bourneville et Sevestre; 1877.

21 Mann A. Congenital absence of the gallbladder. Calif Med. 1957;86(4):280-2.

22 Gazis A, Pound N, Macfarlane R, Treece K, Game F, Jeffcoate W. Mortality in patients with diabetic neuropathic osteoarthropathy (Charcot foot). Diabet Med. 2004;21(11): 1243-6.

23 Stedman TL. Stedman's medical eponyms. 2nd ed. Baltimore: Lippincott, Williams \& Wilkins; 2005. p. 133.

24 Gubler A. Paralysie de la troisème paire droite, récidivant pour la troisème dois. Gaz Hôp Civ Mil. 1860;33:65-6.

25 Charcot J-M. Sur un cas de migraine ophtalmoplégique. Prog Med. 1890;18(83-6):99102.

26 Gelfand AA, Gelfand JM, Prabakhar P, Goadsby PJ. Ophthalmoplegic "migraine" or recurrent ophthalmoplegic cranial neuropathy: new cases and a systematic review. J Child Neurol. 2012;27(6):759-66.

27 Lee D, Dahdaleh N. Charcot spinal arthropathy. J Craniovertebr Junction Spine. 2018; 9(1):9-19.

28 Reynolds BM, Dargan EL. Acute obstructive cholangitis; a distinct clinical syndrome. Ann Surg. 1959;150(2):299-303.

29 Charcot J-M. Leçons sur les maladies fu foie, des voies biliaires et des reins faites à la Faculté de Médecine de Paris. In: Delahaye A, editors. Paris: Bureaux du Progrès Médical; 1877.

30 Charcot J-M. Diagnostic des formes frustes de la sclérose en plaque. Prog Med. 1879;7:97-9.

31 Nakazato Y, Ogawa A, Kawarai M. Histochemical and electron microscopic studies of Charcot-böttcher crystalloids in human sertoli cells. Kitakanto Med J. 1982;32(6):54752.
32 Bouchard CJ. Etude sur quelques points de la pathogénie des hémorrhagies cérébrales. $\mathrm{Pa}$ ris; 1867.

33 Cai SY, Boyer JL. Bile infarcts: new insights into the pathogenesis of obstructive cholestasis. Hepatology. 2019;69(2):473-5.

34 Pryse-Phillips W. Companion to clinical neurology. 2nd ed. New York: Oxford University Press; 2003. p. 470.

35 Tiberghien D. The chair of mental and brain diseases: charcot's pupils: Benjamin Ball, Alix Joffroy and Gilbert Ballet. Front Neurol Neurosci. 2011;29:36-51.

36 Rodríguez RA, Sarmiento L, Rodríguez G. Los cristales de Charcot-Leyden. Biomedica. 1998;18(1):89.

37 Pareyson D, Marchesi C. Diagnosis, natural history, and management of Charcot-Marietooth disease. Lancet Neurol. 2009;8(7):65467.

38 Charcot J-M, Marie P. Sur une forme particulière d'atrophie musculaire progressive, souvent familiale déutant par les pieds et las jambes et atteignant plus tard les mains. Rey Méd. 1886;6:97.

39 Tooth HH. The peroneal type of progressive muscular atrophy. London; 1886.

40 Venes D. Taber's cyclopedic medical dictionary. Philadelphia: F.A. Davis Company; 2017.

41 Charcot J-M. Un cas de suppression brusque et isolée de la vision mentale des signes et des objets. Prog Méd. 1883;11:568.

42 Wilbrand H. Ein Fall von Seelenblindheit und Hemianopsie mit Sectionsbefund. Dtsch Z Nervenheilk. 1892;2(5-6):361.

43 Walusinski O. A historical approach to hereditary spastic paraplegia. Rev Neurol. 2020 176(4):225-34

44 Erb WH. Über eimen wenig bekannten spinalen symptomenkomplex. Berliner Klin Wochenschrift. 1875;12:357-9.

45 Charcot J-M. Du tabes dorsal spasmodique. Prog Med. 1876;4(45):737-8.

46 Charcot J-M. Du tabes dorsal spasmodique. Prog Med. 1876;4(46):773-5.

47 Charcot J-M. Du tabes dorsal spasmodique. Prog Med. 1876;4(47):793-5.

48 Hutchinson J. A case of congenital absence of hair with atrophic condition of the skin and its appendages. Lancet. 1886;1:923.

49 Souques A, Charcot J-B. Géomorphisme cutané. Nouv Iconogr La Salpêtrière. 1891; 4(169-178). 